Woods, D.R. (2018). The UK and the US: Liberal models despite family policy expansion? In G.B. Eydal \& T. Rostgaard (Eds.), Handbook of Child and Family Policy (pp. 182-194). Cheltham/Northampton: Edward Elgar Publishing

\title{
The UK and the US: liberal models despite family policy expansion?
} By Dorian R. Woods

\section{INTRODUCTION}

The UK and the US governments design their child and family policy within a liberal model of social policy. This label 'liberal' does not mean 'free and easy' or connote a political 'leftist' orientation of a person or institution. The term 'liberal', instead, characterizes liberal ideas of minimal economic regulation and social policy. The 'liberal' model of the UK and the US connotes a well-running economy will by default boost the prosperity of families. Extensive family policy is therefore superfluous in free markets that supply services for family needs. Such markets encourage individual freedom, flexibility and innovation to meet demand. Free markets and minimal social policy differ, however, and a comparison of the UK and the US is informative for understanding policy diversity among liberal cases. The UK and the US are often at the opposite spectrum of 'liberalism', with their own historical legacies, policy instruments and power dynamics. Even under similar initial intentions and policy instruments, the UK and US have differing trajectories. Readers interested in a liberal model for viable options in cost-containment or austerity measures might be surprised to learn that family policy measures have grown in the UK and US during the last two decades. They have undergone transformations, making family policy more explicit and in some ways more extensive (see Chapter 2 by Gauthier and Koops in this volume; Woods, 2012). Such growth calls for a re-examination of these liberal market-family-state dynamics.

This chapter pursues the following questions: To what extent have developments in the US and the UK followed a liberal family policy agenda and how have they been similar or different? The chapter first outlines the theoretical approach to liberal family policy and how family policy in the UK and the US has been compared. The subsequent and main sections explore British and USAmerican policy developments from the 1980s to the present. In particular, these sections examine 
the agendas, policy settings and instruments of income maintenance, early childhood education and care services (ECEC), tax credits and family leave policies. The final section of the chapter draws conclusions about UK and US similarities and differences in family policy, as well as the development of liberal ideals and approaches.

\section{LIBERAL FAMILY POLICY}

The literature on family policy has consistently labeled the UK and the US as 'liberal' because of their design and justification of policies with classical liberal ideals of minimal state intervention and reliance on the market. Kamerman and Kahn (1997) and O'Connor et al. (1999) were some of the first to explicitly compare 'liberal' family policy across countries (see also Chapter 5 by Lohmann and Zagel in this volume). Kamerman and Kahn's research emerged out of an international study of family policy from the 1970s, one of the first of its kind to systematically categorize family services and instruments. Later, O'Connor et al. explored women's equality within liberal models of Australia, Canada, the UK and the US (1999). They examined data and policy in the areas of employment, social security, ECEC, anti-discrimination, poverty and reproduction policies. A characteristic of liberal family policy, they concluded, is high inequality among women with different family types and labor force participation as well as disparities due to class, race and ethnicity. Additional authors, such as Anttonen and Sipilä (1996), characterize the UK's care system as Anglo-Saxon with an emphasis on means-testing and a focus more on elderly than ECEC services. Other authors, such as Orloff (1993a, p. 20), draw similarities between liberal policy development in minimal service intervention in Britain, Canada and the US, stating that it was politically reinforced through the combination of early targeted insurance-based policies and reactively late developments of additional social policy for the needs of a wider population.

Generally, the liberal cases of the UK and the US are characterized by implicit and residual family policy with a high tolerance for inequality.

Analytically, the liberal British and US-American models have been said to have 'market defamilization': this means that the market overwhelmingly provides family services for families in place of extensive state supports (Esping-Andersen, 1999; Lohmann and Zagel, 2015). For example, the liberal model will promote inexpensive (and widely available) child care through the market. The 'minimalistic' characterization of liberal family policy in current debates originated from Esping-Andersen's (1990) category of liberal states' low 'decommodification' which also describes 
(minimal) state intervention, but in relation to employment regulations and benefits.

Decommodification measures the extent to which the state unburdens individual's risk in the labor market and the term became controversal in terms of its application to women and families. According to Orloff (1993b), the main problem of this analysis was that it could not account for women's inability to head households as men do: constrained by extra responsibilities in the home, women cannot directly engage in the labor market to the full extent that men can and so cannot be similarly 'decommodified' as men. Lewis and Ostner (1994) followed with an examination on the extent to which women's risk is measured, not dependent on the market but dependent on male breadwinners. Responding to these critiques and others, Esping-Andersen adopted the terms 'familization' and ‘defamilization' from Lister (1994) and McLaughlin and Glendinning (1994). The terms are complementary to decommodification: Before decommodification can take place, 'familization' and 'defamilization' set the stage relative to how families care for their members and are available to work in the labor market. Extensive defamilization, in effect, frees the family from extra care duties so that they can engage in paid employment. Once family members enter the labor market, according to this analysis, varying degrees of decommodification can follow (see more on these arguments in Woods, 2006).

However, the original intention of measuring/evaluating an individual's risk is lost in the various steps of defamilization and this is particularly problematic for examining family policy in liberal models. First of all, the assumed time sequence of defamilization (i.e., it must occur before commodification and decommodification) does not apply in a liberal model because adults with care responsibilities do not wait to be defamilized before they enter the labor market. 'Market defamilization' can only apply to some families who have the means to afford ECEC at market prices (even if these prices are relatively low). In the liberal model, often child care is privately organized among extended relatives or neighbors, or there is the phenomenon of latch-key children among low-income families. Differences in purchasing power affect the access to (quality) care and reduction of overall risk of individuals and families. Thus, 'market defamilization' applies so unequally to individuals and families in liberal welfare state models that it is difficult to apply the term for family policy in general or to measure/evaluate individual's or families' risk in particular. Instead, the term 'market defamilization' seems to describe a liberal state's prevailing high tolerance for unequal access to family supports.

And yet, it is questionable to characterize liberal welfare states as having only negligible state intervention and a more nuanced exploration of liberal family policy is needed. In order to better 
illustrate liberal family policy in light of this ambiguity, the chapter examines the UK and the US because the literature differentiates between them as two opposites on a liberal spectrum. The US is often called the 'exceptional' welfare state because of its extremes. For example, the US has been characterized as a 'pure liberal welfare state' with high inequality (Castles and Mitchell, 1993). O'Connor et al. emphasize the US primacy of the market and its more severe public and private division compared to the UK (1999, pp. 28-9, 226-7). Many authors have pointed to a 'gender sameness' strategy in US politics for creating social policy that emphasizes women's and men's similar needs while de-emphasizing gender role differences in child bearing/care, elderly care or household responsibilities (Lewis, 2009; O’Connor et al., 1999; Tippin and Baker, 1999). On the other hand, the UK has often taken a 'difference' approach, which is apparent, for example, in how many policies were initially established and developed for mothers. While the UK follows a liberal focus of means-testing and targeting certain groups in benefits, many of these programs fall under a larger rubric of social services and this has consequences for the extent and eligibility of benefit receipt as well as for policy legitimization. For example, the UK's income assistance program supplies support for a wide range of clientele, and does not primarily target single mothers as the US does. Most notably, the UK has a history of universal health care and a larger public housing sector than the US, so that social intervention is more embedded in the UK system (Walker and Wiseman, 2003; Woods, 2012).

Differences between the UK and the US can be observed in the spending levels, poverty rates and 'generosity' of benefits. Table 14.1 illustrates that the UK spent 4.3 percent of its gross domestic product (GDP) on family benefits in 2011 compared to 1.11 percent in the US. ECEC expenditure is similarly more generous in the UK where spending was 1.1 percent compared to 0.04 percent of GDP in the US. Poverty rates in liberal countries tend to be high but the UK brought its child income poverty rate down to 10.4 percent in 2011, lower than the average of 13 percent for Organisation for Economic Co-operation and Development (OECD) countries, while the US had a child income poverty rate of 20.9 percent. A comparison of poverty rates by household seems to indicate that the US depends on the job market to reduce poverty (Table 14.1) as households with more earners have fewer rates of poverty. 
Table 14.1 Family and family policy characteristics

\begin{tabular}{|c|c|c|c|}
\hline & UK & US & $\mathrm{ECD}^{\mathrm{a}}$ \\
\hline & UK & US & OECD \\
\hline Total public spending on family benefits (\% of GDP) $2011^{\mathrm{b}}$ & 4.3 & 1.2 & 2.55 \\
\hline Child income poverty rate ( $\%$ of children $0-17) 2012^{c}$ & 10.4 & 20.9 & 13.3 \\
\hline \multicolumn{4}{|l|}{ Poverty rates by households with at least one child (\%) $2012^{\mathrm{c}}$} \\
\hline One adult, jobless & 27.7 & 84.7 & 62.6 \\
\hline One adult, one earner & 7.5 & 33.1 & 20.0 \\
\hline Two adults, jobless & 37.2 & 64.0 & 60.7 \\
\hline Two adults, one earner & 13.1 & 24.8 & 19.6 \\
\hline Two adults, two earner & 2.3 & 5.1 & 4.0 \\
\hline All households & 9.8 & 16.0 & 10.3 \\
\hline \multicolumn{4}{|l|}{ Total public spending on ECEC (\% of GDP) $2012^{\mathrm{d}}$} \\
\hline & 1.1 & 0.4 & 0.8 \\
\hline \multicolumn{4}{|l|}{ Children in public child care by age (\%) $2013^{\mathrm{e}}$} \\
\hline $0-2$ year olds & 35.1 & 28.0 & 32.9 \\
\hline $3-5$ year olds (2012) & 96.3 & 65.7 & $82.0^{\mathrm{f}}$ \\
\hline \multicolumn{4}{|l|}{ Out-of-pocket child care costs (\% of family net income) $2012^{\mathrm{g}}$} \\
\hline Dual earner (full-time earnings, $150 \%$ of average wage) & 34.0 & 29.0 & 13.0 \\
\hline Single parent (full-time earnings, $50 \%$ of average wage) & 8.0 & 52.0 & 14.0 \\
\hline \multicolumn{4}{|l|}{ Maternal and paternal leave length (weeks) $2015^{\mathrm{h}}$} \\
\hline Maternal paid & 39.0 & 0.0 & 52.6 \\
\hline Maternal protected & 70.0 & 12.0 & n.a. \\
\hline Paternal paid & 2.0 & 0.0 & 9.1 \\
\hline Paternal protected & 20.0 & 12.0 & n.a. \\
\hline \multicolumn{4}{|l|}{ Employment rates (\%) 2013} \\
\hline All men aged $25-54^{\mathrm{i}}$ & 86.5 & 82.8 & 84.9 \\
\hline All women aged $25-54^{\mathrm{j}}$ & 75.2 & 69.3 & $71.8^{\mathrm{f}}$ \\
\hline Mothers (15-65) with at least one child aged $0-14^{\mathrm{j}}$ & 66.6 & 65.0 & $66.8^{\mathrm{f}}$ \\
\hline Fertility rate $2014^{\mathrm{k}}$ & 1.8 & 1.9 & 1.7 \\
\hline
\end{tabular}

Notes:

a. OECD-30 average, when not otherwise noted.

b. http://www.oecd.org/els/family/database.htm - PF1_1_Public_spending_on_family_benefits_Oct2013-1

c. http://www.oecd.org/social/family/database.htm - CO2.2 Child Poverty

d. http://www.oecd.org/els/family/database.htm - PF3.1 Public spending on childcare and early education.

e. http://www.oecd.org/social/family/database.htm - PF3.2 Enrolment in childcare and pre-school. 
f. OECD-28 average.

g. https://www.oecd.org/els/soc/PF_3_4_Childcare_support_May2014.pdf

h. https://www.oecd.org/els/soc/PF2_1_Parental_leave_systems.pdf - total paid leave available to mothers.

i. https://stats.oecd.org/Index.aspx?DataSetCode=LFS_SEXAGE_I_R

j. http://www.oecd.org/els/family/database.htm - LMF1.2 Maternal Employment

k. https://data.oecd.org/pop/fertility-rates.htm

The UK and the US also illustrate variance in state intervention, for example, in family leave.

Maternal paid leave in the UK is 39 weeks (with 52 weeks of protected leave altogether). The US is 'exceptional' in that it has no federal compensation for maternity leave but 12 weeks a year of protected unpaid leave for both mothers and fathers. There are a few states that provide paid leave, such as California, but availability of this is usually dependent on employers. Out-of-pocket ECEC costs are 52 percent of family net income for single parents in the US. In contrast, out-of-pocket ECEC costs for single parents in the UK are 8 percent because of a directed effort to reduce costs for this household type. The labor force participation rate of mothers in the UK and in the US is similar with 66.6 percent and 65 percent, respectively (with an OECD average of 66.8 percent) and fertility rates (1.8 and 1.9 percent, respectively) are also similar to the OECD average (1.7 percent).

Varying degrees of 'targeting' and 'generosity' in family policies beg the question as to how the UK and the US, as liberal models, have grown and developed in the past couple of decades and how they have (or have not) towed a liberal line of policy. The UK experienced a series of programs as it transitioned from the austerity era of the Thatcher and Major governments to an explicit expansion in the Blair and Brown governments to the Liberal/Conservative Coalition under Cameron and the subsequent May government. In the same way, the US has developed clear family policy instruments as it progressed from the administrations of Reagan and Bush Sr into the Clinton and then Bush Jr administrations, then into the Obama and now the Trump administrations.

\section{UK CHARACTERISTICS AND DEVELOPMENTS}

The UK experienced the most dramatic changes to family policy in the late 1990s and 2000s. In the previous decades leading up to this, the Thatcher and Major governments had consistently curbed policy measures with cuts in spending and eligibility. In conjunction with 'Thatcherism', the government, for example, froze the universal child benefit in 1987 and let one-parent allowances erode in their real value over time. These policies became less central as family policies, and the means-tested programs, such as the Income Support and a new Family Credit program, grew more prominent. The eligibility criteria became more stringent for the means-tested Family Credit and 
Income Support so that dual-earner families dropped out of this program and the clientele became narrower, creating more stigmatizing effects for the policy. The Family Credit had an in-work allowance, but, at the same time, the Conservative government was ambivalent about work incentives for mothers. To ease poverty in low-income single-parent family households, the government, instead, focused on child support enforcement as a policy. But the policy proved unpopular and difficult to enforce. Aside from income-based policy, there was a growing public demand for ECEC. The debates around ECEC had become so present in the public sphere that John Major, in his campaign for prime minister, followed his rivals and pledged universal nursery education for 3- and 4-year-olds. In 1994 the new Major Conservative government introduced nursery vouchers and a means-tested ECEC supplement for those not receiving support through the Family Credit. Both the residual nature of these Thatcher and Major policies as well as the government's turn to market solutions for family policy can be characterized as 'liberal' family policy.

In 1997 the Blair government won a landslide victory with the New Labour 'Third Way' agenda which transformed family policy in the UK from what it had been. Labour's New Deal program was a welfare-to-work program embodying new ideas of the incoming party. It had aimed first to reduce the high unemployment rates of young people, but quickly the government expanded New Deal clientele to all those economically inactive or 'workless', including single mothers. Initial pilot studies and then a full New Deal for Lone Parents program targeted single parents with school children first, and was then extended to parents with younger children, and eventually to children under 3 years of age. Voluntary interviews and counseling evolved into mandatory requirements. Emphasizing the responsibility to work in order to achieve independence, the government argued that it was committed to ending social exclusion through employment. Also, the government set out a national goal to halve child poverty by 2010 and eradicate it by 2020 . As part of this plan, the new government set up a National Childcare Strategy, the Sure Start programs and the Childcare Tax Credit to replace the Conservative nursery voucher system and the child care supplement. Officials explicitly stated in policy papers that the scarcity and cost of good quality ECEC were recognized as indubitable reasons why women in particular, and especially lone parents, were not able to take up paid work (Wheatley, 2001, pp. 47-8). Bringing down high prices of care and improving services would encourage women's employment. ECEC support would assist parents and single mothers in low-paid work and prevent poverty: a mother's employment and earnings would be important in preventing low incomes, and these earnings could in turn also 
benefit the national economy by reducing the number of families relying on means-tested benefits (Brown, 1997, sec. 121). This was a high-profile issue to promote 'social inclusion instead of exclusion'. The Sure Start program was loosely based on Head Start in the US and was targeted at improving disadvantaged children's care and education. New Labour broke substantially away from previous family policy in its expanse and explicitness. At the same time, true to liberal ideals, Labour emphasized means-testing and focused on child care in mainly disadvantaged areas. In addition, couched in liberalism, the Labor government promoted 'partnerships' between the private and public sector for ECEC enlargement as a conglomerate of local initiatives with business associations.

The Labour government promoted mothers' employment as it stimulated employment in general with tax credits and incentives for low-income families. The government first replaced the Family Credit with Working Families' Tax Credit in 1999 and eventually changed it to the Working Tax Credit, phased in during 2003 and 2004. This credit was inspired by the US Earned Income Tax Credit that gives working low-income families and individuals additional payments (depending on hours worked) to boost overall income. As in the US, the credit was payable through the wage packet and administrated by the Inland Revenue (instead of the Department of Social Security). This symbolically emphasized work and not benefits. In addition, the government introduced a minimum wage. Policies shifted focus away from a breadwinner model towards policies that focused on families with children regardless of marriage status: the Children's Tax Credit was a non-refundable tax credit for two years from the period April 2001 to April 2003. It replaced the Married Couple's Allowance (MCA) from the previous Conservative government. Through the new policy, married couples without children lost a tax break, and families with children saw their tax break more than double in value, especially advantaging families with children under 1 year of age (Brewer and Gregg, 2003). Its predecessor, the Child Tax Credit, was also means-tested: the Labour government continued to uphold mothers' employment but it focused on targeted and means-tested family policy.

Another explicit turn-around from the previous Conservative government was Labour's maternity and parental leave. It became more far-reaching and more generous than any previous UK family leave. The UK had inherited a maternity pay framework from the Beveridge health insurance plan. This was later linked to maternity leave but by the time the Conservative government succeeded in 1979, its terms of eligibility and pay was complex. The 1980 and 1982 Employment Act and the Social Security Act in 1986 actually made it more complicated (Ringen, 1997, 
pp. 51ff.). During the 1980s, the Conservative government also restricted the Protection of Pregnant Women at Work, weakening women's right to return to their jobs after pregnancy. While the European Community was developing its social plan (including a minimal family leave) in the 1980s, the UK did not sign the Social Charter in 1989, ignored the Maastricht Treaty 1991, and refused to accept the European Council Directive EEC 92/85 on Pregnant Workers in 1992. But with pressure from Europe, the Conservative government offered alternatives in the Trade Union Reform and Employment Rights Act 1993. Maternity rights were extended to 14 weeks of maternity leave with statutory sick pay and eligibility was improved by reducing the length of service qualification to 12 months for the higher rates. Momentum grew for family leave as New Labour came to power, and following the European Council Directive (EC) 96/34 on Parental Leave, the government extended maternity leave in 1999 to 18 weeks of ordinary maternity leave, bringing it in line with the same period for entitlement to Statutory Maternity Pay. Rights for mothers were strengthened and streamlined, with a reduction of the two-year eligibility restriction to one. A right to unpaid parental leave for three months was introduced for parents with children under 5 years of age. The Welfare Reform and Pensions Act 1999 also expanded Statutory Maternity Allowance so that more low-income women were eligible (Ogus et al., 2002, p. 560). For the first time, in 2003, paid paternity leave was enacted and adoptive parents were included.

The dramatic increases in (comparatively generous) explicit UK family policy during the Labour government have not been seen since, although the Liberal/Conservative Coalition government under Cameron placed its own accents on family policy. Interestingly, family issues remained a central aspect in social policy for the government, documented by the announcement of the prime minister that all domestic policy would be subject to a 'family test' to understand its impact on families. As Knijn, Martin and Ostner explain in Chapter 12 on parental policy reform generally in this volume, the Cameron government focused on Conservative values of family, minimal government and individual responsibility. One example of this was the government's replacement of Labour's welfare-to-work Job-seeker's Allowance and Income Support with Universal Credit. Recipients of Universal Credit are required to accept and sign contracts ('claimant commitments') with their case workers ('work coaches') before receipt of benefits. Outlined are responsibilities to find work, or if recipients are already in work, they must increase their earnings. Sanctions or cuts in benefits can last up to three years. Work requirements, however, were eliminated for 'primary carers' with children under 3 years of age. Part-time work is required for primary carers when children are aged 3 to 12, and Universal Credit requires full-time work for 
carers when their children are aged 13 and older. The Credit is no longer paid to the individual, but rather paid in a lump sum to the household. Austerity has been an issue as well: the government has restricted migrants' access to Universal Benefit and added a strong element of combating fraud. New are across-the-board caps on all out-of-work benefits except for the Working Tax Credit. Thus, Housing Benefit, Child Tax Credit, Child Benefit and Maternity Allowance, among others, are calculated together. Single adults are allowed up to $£ 296$ per week, and couples and lone parents are allowed up to $£ 442$ per week. True to liberal ideals of minimal government, the administration has also implemented a program that incentivizes personal responsibility of divorced parents to negotiate their own arrangements around child maintenance.

These current developments emphasize individual responsibility and place many family obligations of individuals back into the private sphere. Family policies have remained explicit, but more emphasis has been on austerity, sanctions and targeting - as well as on personal responsibility and individual (or city) 'contracts' with the government. For example, the Troubled Families program is designed to provide financial support to communities dealing with difficult individuals and their families. The government pays the promised lump sum only in full, dependent on whether services have positive results. The community concentrates on servicing families whose members are involved in 'anti-social behavior' and crime, families that have truant children, or families that have an adult on out-of-work benefits and where a family has caused the community high costs. Targeting specific recipient groups is typical of liberal policy and instrumenting means-testing measures (often with stigmatization) is in line with liberal welfare state policy making. However, these last examples show that services explicitly bind individuals more closely to familial units. By concentrating on families and not individuals, policy is practicing a form of familialization, not defamilization. This short historical view seems to show that defamilization, or the unburdening of familial risk, tends to fluctuate, depending on outside pressures and who is in power. When the Labour government incorporated defamilization in the late 1990s and early 2000s, the party bound this closely with business and market partnerships, clearly a form of market defamilization. In all, however, the above policy-making examples from both Conservative and Labour parties show that liberal policies explicitly aim to intervene in directing family members' behavior, which is not necessarily the 'neutral' policy espoused for liberal non-intervention in families and the market. 'Liberal' policy seems to intervene readily into families. 


\section{US CHARACTERISTICS AND DEVELOPMENTS}

Just as tensions and differing interpretations of family policy arose in the UK between the Conservative and Labour governments, so too did Republicans and Democrats place distinct accents on the unfolding of US family policy. Especially in the 1990s, the policies were reinterpreted and transformed from the Reagan/Bush era to the Clinton administration. As Thatcherism boomed in the UK, the Reagan administration promoted what was to become known as 'Reaganomics', introducing large cuts in government expenditure on social policy and reducing taxes as well as embarking in decentralization. Austerity measures for social policy were conveyed with the idea of paternalism, that is, a state's encouragement through policy to promote benefit recipients' self-sufficiency. Similarly to the Thatcher and Major governments, the Reagan and Bush Sr governments were ambivalent about mothers' employment, first reducing work incentives in social assistance and then reintroducing them. The government's first 1981 budget reduced social assistance eligibility, income disregards in benefit calculations and recipients' deductions for workrelated and ECEC expenditures. This caused a certain type of welfare recipient to slowly emerge, as some recipients lost eligibility because of too high earnings and others reduced their employment to stay on benefits and receive Medicaid. Seven years later, the Family Support Act reintroduced work-oriented family allowances with increased earnings disregards, transitional ECEC and Medicaid. Added was the Job Opportunities and Basic Skills Program (JOBS) that required training participation for women and workfare for Aid to Families with Dependent Children (AFDC)recipient fathers. Implicitly, the policies became more targeted in the first stage but reached a wider recipient pool in the second round. Still, the employment of fathers was emphasized more than mothers. A significant change to social assistance under the Republican administration was the programs' elements of decentralization, as legislation allowed states to experiment. These state trials could include 'family caps' (i.e., denial of additional benefits for children born while a mother is still on welfare), work requirements, provision of cash supplements for the education of lowincome workers, as well as time limits on cash benefits.

ECEC under the Reagan and Bush administrations was interpreted through distinct liberal ideals. As public pressure for improved ECEC arose, Democrats proposed the Act for Better Child Care (ABC) in 1987. This would have established federal grants for ECEC for low-income families, improved ECEC for all families and created national standards. As an alternative, the Republicans offered tax credits and vouchers, concentrating on means-tested ECEC for low-income families. As 
a compromise, the Child Care and Development Block Grant and the At-Risk Child Care Program were enacted as part of the Omnibus Budget Reconciliation Act of 1990. The legislation was the first of its kind to extend beyond families on social assistance and provide low-income families with ECEC. However, the Republican Party was more interested in expanding the Earned Income Tax Credit (EITC) as an alternative to publicly funded ECEC. Republicans argued that the EITC refund money would give families an individual choice to pay for ECEC or perform it themselves. These tax returns might support a traditional male breadwinner model, if families chose to compensate one parent to stay out of the workforce. The Republican administration found the EITC attractive, and considerably expanded it twice. The other expansion took place in 1986, as Congress was negotiating tax reform in the budget and the Democrats and Republicans were at loggerheads on raising the minimum wage.

Coming to power in 1993, the Clinton administration offered an alternative direction for family policy. In the election campaign, Clinton proposed 'ending welfare as we know it' with drastically changing welfare policies, ECEC and family leave. On the one hand, expansive policies were put on the table, such as universal child care and universal health care as well as more generous instruments that would 'make work pay' (such as a wider-reaching EITC). On the other hand, in the process of recreating itself in the election process, the Democratic Party publically shifted its ideology: the party of 'New Democrats' embraced the dominant discussion around fiscal and personal responsibility as well as self-sufficiency. Also, as a former governor, Clinton was not opposed to devolution of national policy to the state. These new ideas laid the foundation for a different dynamic in the negotiations over policy. For example, discussions around social assistance were focused more on single mothers and employment, and less on issues such as poverty and children (Weaver, 2000). Furthermore, Clinton adopted family leave as a major issue. In his election campaign, Clinton had promised to sign the Family and Medical Leave Act (FMLA) into law after the bill had gone through several transformations and two vetoes during the Bush $\mathrm{Sr}$ administration. From early on in the bill's development, policymakers had settled for an unpaid leave in their negotiations with coalition partners, considering a paid leave as too controversial for getting the necessary votes in Congress (Elving, 1995). The Clinton administration signed it unchanged as their first law in 1993, and the FMLA became the first US national family leave policy to protect employees from losing their job for missing work due to familial or medical reasons. 
The beginning of Clinton's administration saw policy movements on other fronts. The 1993 Omnibus Budget Reconciliation Act increased the maximum credit rate available for the EITC and the income level at which individuals could qualify for the credit. It also allowed certain lowincome taxpayers without children to receive the credit for the first time. The Republican control of Congress in 1996 with the 'Contract with America' campaign narrowed Democrats' room to negotiate family policy, however. By connecting child care to welfare (to work programs), the Clinton administration showed that it considered ECEC as a workforce issue. The Clinton administration held a readiness to 'leave it to the states' so that block grants for social assistance and ECEC became quickly uncontested. Since this legislation, individual states have the discretion to direct this funding to ECEC as they see fit or redirect it to other programs. The ensuing Child Care Development Block Grant no longer entitled single parents to ECEC and established no federal requirements for care quality. A two-year limit on welfare payments was introduced with a lifetime five-year limit that parents had to benefits. After 1996, Congress and the administration could not agree on further developments for the EITC.

There has been little family policy change on the US federal level since the transformations into more explicit US family policy during the Clinton administration. The law Temporary Assistance for Needy Families (TANF) with the child care block grants still stands from 1997. Just as the UK has continued to uphold the importance of family in its current political discussions around policy, so too have recent adminstrations emphasized family. However, the Obama administration set accents on fathers' roles in families. For example, state programs focused on preparing fathers for gainful employment, for their taking more responsibility for child care maintenance and child involvement. Policy discussions in the Obama administration placed less political intensity on single mothers' employment compared to the TANF debates during the Clinton administration. Because of the difficulty of the Obama administration and Congress' ability to pass federal budgets, temporary funding to bridge gaps increased the precariousness of policies and burdened the states' abilities to plan long term. On the other hand, momentum for family policy innovation and change can be observed at the state level for paid family leave, such as the expansion of eligibility or leave length. Paid programs were implemented in California in 2004, New Jersey in 2009, Rhode Island in 2014 and New York in 2016. Insurance programs that act similarly to parental leave are also in place in Hawaii, Washington, DC and Puerto Rico. The proposed family policy from the Trump administration includes ECEC and paid maternity leave, but there remain some questions about how this policy will develop in Congress, because of costs, 
estimates of negative effects for low-income families and its targeting of only mothers, not to mention partisan politics that has made policy making difficult. In 2015 President Obama issued a presidential memorandum for federal employees to receive up to six weeks of paid leave after birth, adoption or fostering of a new child, and the Trump administration has followed suit with interest in supporting a bill introduced in Congress with this legislation. These changes all point to more US government involvement in family policy, which is not necessarily a liberal trait. However, because ECEC is targeted to the very needy and not guaranteed, the EITC is means-tested and family leave regulations are unpaid (and cover only about half of the working population), all characteristics point to liberal tendencies. Policies remain rudimentary and decentralized, so that a more detailed account of market defamilization would need to be examined on the individual state level. Just as in the UK, however, the US has explicitly aimed to direct family behavior, and this involvement stands in contrast to liberal welfare states' minimal involvement in market regulations and family affairs.

\section{CONCLUSION}

The family policies in the UK and the US have progressed somewhat similarly. Since the 1980s the UK and the US have instrumented a series of programs that have made family policy more explicit. These developments were especially apparent in the 1990s and early 2000s. The UK and the US considerably expanded their family leave, tax credits and, at certain junctions, they broadened public ECEC to include not only social assistance recipients but also low-income families - a policy otherwise instituted only during historical war times. The UK and the US overhauled policies addressing parents' employment and streamlined welfare-to-work programs. In many cases, they appropriated ideas and policy from one another: for example, the Blair government borrowed extensively from the Clinton administration on single mothers' employability and on tax credits for low-income families. The UK and the US have both made families and parenting more of a public concern, and expanded policy, for the most part, by emphasizing 'activation' into employment.

Explicit and expanded family policy is, on first consideration, surprising and uncharacteristic of liberal states in itself. However, this might not be so surprising after observing general trends in family policy expansion across developed welfare states, as documented in other chapters of this Handbook. And UK and US expansion has consistently emphasized liberal ideals with minimal policy. This is apparent in the welfare states' insistence on building partnerships with business 
communities and in repeated exploration of market solutions for social problems, such as vouchers and business tax breaks (e.g., in ECEC). The liberal idea of personal responsibility is epitomized in the continuous contractual emphasis of benefit receipt. For example, policy has been justified on the grounds that it helps individuals 'lift themselves out of poverty' and government support should be a 'hand up' instead of a 'hand-out'. The UK and the US have followed a liberal family policy agenda in that they emphasize means-testing for the very needy and encourage the market and employment to be solutions for poverty and social risk problems. This is so much so that the market should work: for example, political discourse in the Clinton administration and the Blair government emphasized 'it must pay to work'. This has been echoed in current UK political discourse around raising the minimum wage. Liberal ideals of labor market participation, freedom and choice have been an integral and consistent part of the expansion and explicitness of family policy in the UK and the US.

While the UK and the US have experienced similar trajectories, some issues seem to stand out in having particularly influenced differing policy developments. First of all, party politics and institutional settings were extremely important in each case. The need for congressional consensus played and still plays a decisive role in the US. This has tended to promote compromises for minimal standards during policy making. The UK, on the other hand, has been held to more generous European standards that has tended to encourage more largesse. A second issue, related to the first, was the UK's high child poverty rate in the 1990s and the Labour government's commitment to eliminating it. This made it easier to justify higher benefits for needy families with children and reform across policy areas - not just in activation policies. In contrast, policymakers in the US have focused on poverty primarily as an employment issue. This encourages reform to focus less on children than on adult policy recipients. Less focus on child vulnerability encourages less generosity in coverage. A third significant difference between the UK and the US has been approaches to gender roles. The consideration of policy impact on men and women has had more of a presence in policy making in the UK than in the US. For example, the Blair, the Brown and the Cameron governments continuously addressed whether benefits should be paid to the 'purse' or the 'wallet', indicating that the choice of benefit recipient (the carer or the breadwinner) ultimately influences how family members share or redistribute their resources. US policymakers have deemphasized gendered effects of redistribution within the household and more readily take a genderneutral approach. Race and ethnity has been a fourth issue that has been incorporated in policy making differently in the UK and the US. For example, US social assistance policy-making debates 
in the 1990s characterized recipients as African-Americans, and this perception and dialog of 'otherness' might have encouraged less solidarity generally. On the other hand, the Labour Party debated social assistance reform with repect to how it impacted different community groups.

Overall, the UK and US have constantly upheld liberal ideals during an uncharacteristic expansion of explicit family policy, even if their policy has varied in generosity and eligibility, but a nuanced exploration of family policy development in these two opposite sides of the liberal spectrum exposes some issues. The UK and the US have consistently upheld the primacy of the market for solving social problems, for example, with means-testing or with private partnerships in public services, but when policy in the UK and the US remains minimal, we still know very little about what this means for family members' interdependence (familization) or the extent of market defamilization to unburden familial responsibilities. Indeed, differences in generosity in allowances and eligilibity - as well as their gendered and racial impacts - calls for a closer examination of familization and defamilization characteristics in liberal regimes and social risk. This chapter illustrates that the US and the UK deliberately intervene into family lives and explicitly aim to influence individual behavior. This calls into question the very nature of what 'liberal' claims, in terms of encouraging freedom and individual choice. It seems as if liberal policy has different standards for families than for the markets. This chapter chronicles policy making in the UK and the US with comparable liberal ideas, policy instruments and institutional settings for family policy developments, and provides food for thought in terms of liberal states' involvement in families' lives.

\section{REFERENCES}

Anttonen, A. and J. Sipilä (1996), 'European social care services. Is it possible to identify models?', Journal of European Social Policy, 6 (2), 87-100.

Baker, M. and D. Tippin (1999), Poverty, Social Assistance, and the Employability of Mothers: Restructuring Welfare States, Toronto: University of Toronto Press.

Brewer, M. and P. Gregg (2003), 'Eradicating child poverty in Britain: welfare reform and children since 1997', in R. Walker and M. Wiseman (eds), The Welfare We Want? The British Challenge for American Reform, Bristol: Polity Press, pp. 81-114.

Brown, G. (1997), The Chancellor's 1997 Budget Speech, HM Treasury, accessed 2 July 2003 at http://archive.treasury.gov.uk/pub/html/budget97/speech.html 
Castles, F.G. and D. Mitchell (1993), 'Worlds of welfare and families of nations', in F.G. Castles (ed), Families of Nations: Patterns of Public Policy in Western Democracies, Aldershot: Dartmouth, pp. 93-128.

Elving, R.D. (1995), Conflict and Compromise: How Congress Makes the Law, New York: Simon and Schuster.

Esping-Andersen, G. (1990), The Three Worlds of Welfare Capitalism, Cambridge: Polity Press. Esping-Andersen, G. (1999), Social Foundations of Postindustrial Economies, Oxford: Oxford University Press.

Kamerman, S.B. and A.J. Kahn (eds) (1997), Family Change and Family Policies in Great Britain, Canada, New Zealand, and the United States: Family Change and Family Policies in the West, Oxford: Clarendon Press.

Leitner, S. (2003), 'Varieties of familialism. The caring function of the family in comparative perspective', European Societies, 5 (4), 353-75.

Lewis, J. (2009), Work-family Balance, Gender and Policy, Cheltenham, UK and Northhampton, MA, USA: Edward Elgar Publishing.

Lewis, J. and I. Ostner (1994), 'Gender and the evolution of European social policies', ZeSDiscussion paper, Bremen, pp. 1-62.

Lister, R. (1995), 'Dilemmas in engendering citizenship', Economy and Society, 24 (1), 1-40. Lohmann, H. and H. Zagel (2016), 'Family policy in comparative perspective: the concepts and measurement of familization and defamilization', Journal of European Social Policy, 26 (1), $48-65$.

McLaughlin, E. and C. Glendinning (1994), 'Paying for care in Europe: is there a feminist approach?', in L. Hantrais and S. Morgan (eds), Concepts and Contexts in International Comparisons: Family Policy and the Welfare of Women, Longborough: Center for European Studies, pp. 62-9.

O’Conner, J.S., A.S. Orloff, and S. Shaver (1999), States, Markets, Families. Gender, Liberalism and Social Policy in Australia, Canada, Great Britain and the United States, Cambridge: Cambridge University Press.

Ogus, A.I., E.M. Barendt, and N. Wikeley (eds) (2002), The Law of Social Security, 5th edn, London: Lexis Nexis.

Orloff, A.S. (1993a), The Politics of Pensions: A Comparative Analysis of Britain, Canada and the United States, 1880s-1940, Madison, Wi: University of Wisconsin Press. 
Orloff, A.S. (1993b), 'Gender and the social rights of citizenship: state policies and gender relations in comparative research', American Sociological Review, 58 (3), 303-28.

Ringen, S. (1997), 'Family change and family policies: Great Britain', in S.B. Kamerman. and A.J. Kahn (eds), Family Change and Family Policies in Great Britain, Canada, New Zealand, and the United States: Family Change and Family Policies in the West, Oxford: Clarendon Press, pp. 29-102.

Walker, R. and M. Wiseman (eds) (2003), The Welfare We Want? The British Challenge for American Reform, Bristol: Polity Press.

Weaver, R.K. (2000), Ending Welfare as We Know It, Washington, DC: The Brookings Institute.

Wheatley, J. (2001), WFTC Work in Progress: CAB Clients Experiences of Working Families' Tax Credit, London: National Association of Citizens Advice Bureau.

Woods, D. (2006), 'Focusing on care. Family policy and problems of analysis', WiP Working Paper Series, No. 30, accessible at http://www.wip-online.org/wip-papers.html

Woods, D. (2012), Family Policy in Transformation: US and UK Policies, Houndmills, Basingstoke: Palgrave Macmillan. 